\title{
Carnavalização e multidentidade cultural antropofagia e tropicalismo
}

\author{
DILMAR MIRANDA
}

"[nesta terra] tudo se leva em festas, cantar e folgar"

(pe. José de Anchieta) ${ }^{1}$

RESUMO: O artigo analisa a festa carnavalesca e o fenômeno da carnavalização, a partir da reflexão empreendida por Mikhail Bakhtin, enquanto prática cultural e visão de mundo e de vida, componentes valiosos para o estudo de nossa chamada identidade cultural. $O$ autor procura aportar alguns questionamentos acerca do tema, servindo-se sobretudo de dois movimentos provocadores de um intenso debate na nossa vida cultural em dois momentos distintos da recente história brasileira: a Antropofagia do movimento modernista da década de 20 e o Tropicalismo dos anos 60 .

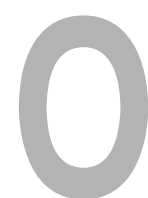

caráter lúdico-festivo presente nas práticas artístico-culturais tem sido contemplado por vários pensadores e analistas do fazer estético. O filósofo Hans-Georg Gadamer, por exemplo, vislumbra em toda experiência estética, seja nos moldes da arte clássica ou da arte moderna, três dimensões constitutivas básicas: a arte como jogo, símbolo e festa (Gadamer, 1985). Anosso ver, esse traço lúdico-festivo representa um campo precioso para o estudo da problemática da chamada identidade cultural brasileira. Neste artigo pretendemos analisar esse traço profundamente

UNITERMOS: festa, carnavalização, multidentidade, cultura, modernidade, antropofagia, tropicalismo.
Professor do Departamento de Ciências Sociais e Filosofia da Universidade Federal do Ceará 
enraizado na nossa cultura, sobretudo a partir das práticas carnavalescas bem como da visão carnavalizada do mundo e da vida decorrente de tais práticas ${ }^{2}$.

A festa carnavalesca é um traço marcante quase onipresente em várias práticas culturais e no imaginário do povo brasileiro. Tal fato, por outro lado, tem se deslocado, com freqüência, para o imaginário estético de intelectuais, como estratégia recorrente privilegiada em suas criações, nas suas mais diferentes modalidades, para dar conta daquela expressividade popular, agenciando a festa, enquanto concepção carnavalizada do mundo e da vida. Citemos, brevemente, três modalidades estéticas marcantes da nossa cultura nacional onde podemos com facilidade identificar tal fenômeno - o cinema, a literatura e a música.

Na filmografia nacional tem sido um traço muito presente nas pulsões criativas de nossos cineastas, seja como marcação temporal, seja como elemento estruturante da narrativa de vários filmes, como podemos ver, a título de exemplo, numa pequena amostra da produção dos anos $60 / 70^{3}$.

Na literatura são vários os exemplos, mas o caso mais paradigmático é certamente o movimento antropofágico presente na obra de Oswald de Andrade, ocorrido no interior do modernismo dos anos 20, pois, mais do que presença marcante, a carnavalização é assumida e radicalizada como postura consciente e norteadora de uma proposta estética. Nele vamos encontrar uma manifestação que, através de dois famosos documentos fundantes - o Manifesto da poesia Pau-Brasil (1924) e o Manifesto antropófago (1928)-, irá liberar um magma criativo de profunda renovação, com ressonâncias decisivas para a cultura brasileira.

Em nossa produção musical é interessante observar que o carnaval tem sido objeto de análises enquanto expressão de um "rito de passagem" ou de um "rito de calendário", conforme conceitua um ensaio do antropólogo Roberto Da Matta, a exemplo da Noite dos mascarados ou Sonho de carnaval, ambas de Chico Buarque de Holanda, ou a Marcha da quarta-feira de cinzas de Carlos Lira e Vinicius de Moraes ${ }^{4}$.

A perspectiva antropofágico-carnavalesca oswaldiana será retomada quarenta anos depois pela Tropicália ${ }^{5}$. Esta fará irromper, de forma intensa e articulada com outras linguagens estéticas (teatro, cinema e artes plásticas), a visão antropofágica e carnavalizada, retomando a linhagem modernista, agora noutro registro histórico e estético, dentro de nossa contemporaneidade ${ }^{6}$.

\section{A carnavalização segundo Bakhtin}

\section{A carnavalização nas práticas populares: história e conceito}

Um autor que desenvolveu um dos estudos mais sugestivos e aportou elementos fecundos para a compreensão do fenômeno da carnavalização foi Mikhail Bakhtin. No clássico A cultura popular na Idade Média e no Renascimento, ao examinar a relevância do riso popular no entendimento do 
contexto da obra de François Rabelais, Bakhtin afirma que "sua amplitude e importância [da carnavalização] na Idade Média e no Renascimento eram consideráveis (...) opunha-se à cultura oficial, ao tom sério, religioso e feudal da época. Dentro da sua diversidade, essas formas e manifestações - as festas carnavalescas, os ritos e cultos cômicos especiais (...) - possuem uma unidade de estilo e constituem partes e parcelas da cultura cômica popular, principalmente da cultura carnavalesca, una e indivisível" (Bakhtin, 1993, p. 3 ss).

Sumariamente, os festejos carnavalescos ocupavam lugar de destaque na vida medieval. Além do carnaval propriamente dito, já existia uma tradição de outras celebrações cômicas, nas quais era forte a presença da visão carnavalizada do mundo e da vida, conforme analisaremos mais adiante, a exemplo da festa stultorum (a festa dos tolos) e do risus paschalis (o riso pascal), para citar dois destaques mais expressivos. Esses ritos cômicos possuíam uma diferença fundamental com relação às modalidades oficiais da Igreja e do poder feudal: edificavam um segundo mundo e uma segunda vida, vivenciado em ocasiões especiais, constituindo uma espécie de dualidade do mund ${ }^{7}$. Essa dupla percepção bem como a prática festiva já existiam desde a alvorada da humanidade.

A festa parece possuir um princípio seminal ${ }^{8}$ da existência humana - forma primordial da civilização ${ }^{9}$. Festa iniciática, mas também presença na travessia e no termo do tempo.

Vejamos mais de perto como se deu esse processo, tendo-se como base da visão de Bakhtin. Durante milênios, a partir dos períodos mais recuados, a percepção e a consciência do tempo sofreram mudanças consideráveis. No princípio, ele é visto como a justaposição do começo e do fim de um desenvolvimento natural: inverno/primavera, morte/nascimento, partes constitutivas de um ciclo vital. "A sucessão das estações, a semeadura, a concepção, a morte, e o crescimento são os componentes dessa vida produtora. A noção implícita do tempo contida nessas antiquíissimas imagens é a noção do tempo cíclico da vida natural e biológica" (Bakhtin, 1993, p. 22). O sentimento que estabelecia um sinal de igualdade entre as sucessivas estações climáticas, com as consequiências naturais do ciclo biológico, é ampliado e aprofundado, abarcando os acontecimentos da sociabilidade humana. Institui-se, assim, o sentimento da temporalidade histórica. No interior de todo esse processo, o rito festivo sempre joga um papel importante na marcação do tempo, seja do tempo cósmico-natural, biológico, seja da temporalidade histórica.

Vida, morte, ressurreição - ciclo recorrente da existência que marca momentos fortes da festa. Vida, morte, ressurreição-ciclo recorrente da festa que marca momentos fortes da existência.

Nos costumes primitivos existia o "riso ritual", oficialmente instituído, espécie de contrafação cômica dos cultos sérios, que convertia o sagrado em motivo de burla, o herói em motivo de paródia e chacota. Bakhtin dá conta de fenômeno similar na Roma primitiva. Por ocasião da celebração de algum triunfo, o vencedor, em igual proporção, era simultaneamente 
escarnecido $^{10}$. Nas cerimônias fúnebres, o morto era objeto de pranto e celebração, bem como de escárnio. Vitória ou fracasso, glória ou vilipêndio, possibilidades antinômicas decorrentes da mesma situação de risco, que precisavam ser sempre lembradas.

O que diferencia esses duplos ritualísticos, entre o mundo primitivo e as sociedades onde prevalece o sistema de classes, como no Estado romano e na Idade Média, é a perda da unidade ritualística, de modo que as formas cômicas, ao se afastarem das formas oficiais, cada vez mais se complexificam e seu sentido modifica-se, configurando formas fundamentais da percepção do mundo constitutivas da cultura popular. Desritualizam-se, ao mesmo tempo em que consubstanciam novas modalidades de expressão popular. Como exemplo Bakhtin cita as saturnais romanas e os carnavais medievais.

No carnaval medieval, o princípio da comicidade ganha autonomia de seu contraponto religioso. Distante de qualquer dogmatismo místicoeclesiástico, os festejos perdem qualquer tipo de caráter mágico ou encantatório, o que ainda se poderia encontrar no riso ritualístico primitivo. Destacase seu caráter de festa pagã. Em certos casos, as formas carnavalescas são autênticas paródias do culto religioso.

A despeito de semelhança com formas teatrais, a festa medieval situa-se entre a arte e a vida cotidiana. Para Bakhtin, existe uma diferença básica entre o teatro e o carnaval da Idade Média. Este ignora por completo qualquer distinção entre ator e espectador. Ignora também o palco. "Pois o palco teria destruído o carnaval (e inversamente, a destruição do palco teria destruído o espetáculo teatral)" (Bakhtin, 1993, p. 6). Os "foliões" não assistem passivos ao carnaval. Participam, vivem, pois o festejo é para todos. Daí seu caráter universal. A lei que preside o carnaval é a lei da liberdade ${ }^{11}$. Na verdade, tudo leva a crer que é o teatro medieval que bebe nos mananciais dos festejos carnavalescos. $\mathrm{O}$ ideal das saturnais romanas vivificadas como um período de retorno, ainda que provisório, a um tempo e lugar "outros" - ao país da idade de ouro - permanece vivo nos festejos medievais, momento privilegiado de suspensão e fuga da rotina e da vida ordinária. Por isso, o carnaval não se constitui como arte de espetáculo teatral, mas é uma forma efetiva, ainda que transitória, da própria vida. Talvez uma forma de efetiva estetização da existência, numa formulação mais contemporânea. Assim, "a forma efetiva da vidaé ao mesmo tempo sua forma ideal ressuscitada"(Bakhtin, 1993, p. 7). Nem teatro, nem representação. Nem atores, nem palco. Momento especial da existência, ao mesmo tempo onírico e real. É a própria vida que representam. Daí não ser representação, mas vivência. Jogam um jogo especial que se transforma em vida real. É aquela dualidade do mundo e da vida - segunda vida do povo, fundada no princípio do riso e da festa.

No carnaval da Idade Média, esse é o caráter específico da segunda vida do povo - o caráter utópico da universalidade, liberdade, igualdade e abundância. As festas oficiais da Igreja e do poder feudal negavam a possibi- 
lidade da segunda vida ao povo. Reiteravam o existente, o presente, pela celebração do passado, pela repetição ritualística do mesmo, do eterno. $\mathrm{O}$ tempo apresentado como mero elo da cadeia da eternidade. A finitude negada e engolfada na infinitude transcendente. $\mathrm{O}$ oficial consagrava o grave, a seriedade. $\mathrm{O}$ riso era um corpo estranho no mundo sagrado.

Essa reflexão bakhtiniana é bastante esclarecedora, por exemplo, para a compreensão do romance $O$ nome da rosa. Um traço marcante do fenômeno da carnavalização é o mundo das inversões. A descrição do "mundo às avessas" desenhado pelo monge miniaturista Adelmo de Otranto, primeira vítima do serial killer do romance de Umberto Eco, ilustra magistralmente esse jogo de espelho do mundo das interversões entre o sagrado e o profano, o sublime e o vagabundo, a verdade e a mentira.

Porém, já estavam prontas outras folhas, e olhando
para elas nem eu nem Guilherme conseguimos conter
um grito de admiração. Tratava-se de um saltério às
margens do qual se delineava um mundo ao avesso
em relação àquilo com que se habituaram os nossos
sentidos. Como se à margem de um discurso que por
definição é o discurso da verdade, se desenvolvesse,
profundamente ligado a ele, um discurso mentiroso
sobre um universo virado de cabeça para baixo, em
que os cães fogem das lebres e os cervos caçam o
leão (Eco, 1995, p. 97).

Entretanto, as passagens mais significativas do romance referentes ao nosso tema estão contidas na série de disputa entre os monges Guilherme de Baskerville, defensor do riso, e Jorge de Burgos, representante da seriedade oficial, no melhor estilo das "quaestiones disputatae" da tradição escolástica. Contra os argumentos intransigentes deste último, Guilherme procura convencê-lo do caráter lícito do riso. Os diálogos são entrecortados com argumentos do tipo "por ser racional, é próprio do homem rir", com depoimentos da vida de santos que teriam manifestado humor até na hora do martírio. Questão suprema: o riso teria feito parte da vida de Cristo ou não? Mas o leit-motiv mais intrigante e fantástico que conduz a trama principal é a existência de um suposto segundo livro da Poética sobre a comédia, onde o Filósofo (Aristóteles) teria feito o elogio do riso, cuja leitura o monge Jorge procura evitar. Para isso, usa de todos os expedientes, inclusive de assassinatos, para preservar aquilo que julga ser certo e lícito - a ordem de um mundo sério e grave.

A festa carnavalesca é o momento da total inversão do regime dominante: a liberação, ainda que provisória, a abolição das hierarquias, regras e tabus, o congraçamento pagão. Desejos oníricos de um lugar outro e de um tempo outro, de uma utopia e de uma ucronia. Tal abolição tem um sentido especial. Nas festas oficiais, as distinções hierárquicas, com insígnias, títulos, discursos e pompas, marcavam intencionalmente as desigualdades. Na festa 
popular, o ideal utópico e o real constituíam uma parte essencial da visão carnavalizada da vida e do mundo. "Em consequiência, essa eliminação provisória, ao mesmo tempo ideal e efetiva, das relações hierárquicas entre os indivíduos, criava na praça pública um tipo particular de comunicação, inconcebível em situações normais" (Bakhtin, 1993, p. 9).

Com o correr dos séculos, o carnaval consubstanciou uma linguagem e procedimentos próprios, uma percepção peculiar e carnavalizada do mundo por parte do povo. A forma simbólica da linguagem carnavalesca caracteriza-se principalmente pela lógica "ao avesso". A linguagem do segundo mundo é a paródia da vida ordinária, do "mundo ao revés”. Para Bakhtin, tal paródia diferencia-se da visão moderna meramente negativa e formal, pois, aquela, mesmo negando a vida ordinária, ressuscita e renova ao mesmo tempo. O riso carnavalesco medieval é "ambivalente: alegre e cheio de alvoroço, mas ao mesmo tempo burlador e sarcástico, nega e afirma, amortalha e ressuscita simultaneamente"(Bakhtin, 1993, p. 10).

A universalidade da festa popular faz com que tudo se torne objeto de burla e deboche, inclusive os próprios debochadores: "o riso popular ambivalente expressa uma opinião sobre um mundo em plena evolução no qual estão incluídos os que riem" (Bakhtin, 1993, p. 11).

\section{A carnavalização na literatura: enriquecimento do conceito}

Bakhtin estende sua análise sobre o fenômeno da carnavalização para além das práticas populares, ou seja, para as narrativas que se utilizam da linguagem carnavalesca. Trata-se de uma literatura prenhe daquela concepção carnavalizada do mundo. Isso ocorre durante toda a Idade Média, conforme atesta a difusão de uma literatura latina paródica ou semiparódica, onde a ideologia cristã feudal, com todos os seus rituais, é descrita a partir de uma perspectiva cômica. A obra mais famosa desse tipo de literatura é A ceia de Ciprião (Coena Cypriani) ${ }^{12}$, que parodia o Antigo e Novo Testamento (toda a literatura oficial judaico-cristã) dentro do espírito carnavalesco, fato que estaria legitimado pela tradição do risus paschalis bem como pelos remotos vestígios das saturnais romanas. Outra obra do gênero é Vergilius Maro grammaticus, erudito tratado semiparódico da gramática latina, da sabedoria escolástica e dos métodos científicos no início da Idade Média. Para Bakhtin, tais obras são inaugurais da literatura carnavalesca medieval, cuja popularidade persiste até o Renascimento.

É ainda nesse período que surge uma linhagem de paródia sacra constituída pelos duplos paródicos de uma numerosa liturgia (liturgia dos beberrões, liturgia dos jogadores), paródias das leituras evangélicas, das orações, inclusive das mais sagradas como o pai-nosso, a ave-maria, as ladainhas, os hinos religiosos, os salmos etc. A moral cristã e os milagres são carnavalizados em maior ou menor grau. O riso e o deboche são traficados para o interior da fé e dos mistérios. Para o autor, essa literatura cômica latina conhece seu clímax no apogeu do Renascimento, com o Elogia à loucura, de 
Erasmo de Roterdam, uma das obras mais criativas do riso carnavalesco da literatura mundial. Como consequiência do fenômeno da carnavalização, presente tanto nas práticas festivas do povo, como na narrativa paródica de uma literatura latina, durante a Idade Média, gestaram-se aos poucos novas formas lingüísticas: gêneros inéditos, interversão de sentidos, extinção de certas formas etc.

Bakhtin destaca, dentre as inovações lingüísticas criadas pelo processo de carnavalização, a incorporação da linguagem familiar e vulgar da praça pública. Esta prima-se pelo uso freqüente de grosserias, de expressões fortes e injuriosas. As grosserias blasfematórias, em tempos primordiais, exerciam funções essencialmente mágicas e encantatórias. Tais grosserias dirigidas às divindades constituíam um elemento básico dos cultos cômicos mais arcaicos. Seu caráter ambivalente degradava e regenerava simultaneamente. Essa ambivalência é transportada para o caráter verbal típico das grosserias da linguagem carnavalesca, perdendo completamente, porém, sua dimensão sagrada e encantatória. Com isso, as grosserias criaram na festa carnavalesca, um clima de liberdade lúdica.

Segundo Featherstone (1995), citando Stallybrass e White, Bakhtin identifica no fenômeno da carnavalização o rito das inversões e transgressões simbólicas, no qual os pares antinômicos - superior/inferior, sublime/vagabundo, erudito/popular, clássico/grotesco - são desconstruídos e reconstruídos, obedecendo a uma lógica de "um mundo ao avesso". "Os autores apóiam-se na obra de Bakhtin, para mostrar como o carnaval envolve a celebração do 'corpo grotesco' - comida farta, embriaguez, promiscuidade sexual - num mundo em que a cultura erudita é posta de cabeça para baixo. O corpo grotesco do carnaval é o corpo inferior da impureza, desproporção, imediatez, orifícios, o corpo material que é o oposto do ‘corpo clássico', belo, simétrico, superior, percebido a distância, o corpo ideal. O corpo grotesco e o carnaval representam a alteridade excluída do processo de formação da identidade e da cultura da classe média" (Featherstone, 1995, p. 113 ss).

Vendo em Rabelais o paradigma recorrente do princípio da vida material e corporal ("imagens do corpo, da bebida, da comida, da satisfação de necessidades naturais, e da vida sexual"-Bakhtin, 1993, p. 16) da linguagem carnavalesca renascentista, Bakhtin enfatiza o caráter hiperbólico e exacerbado do sentido das imagens cumprindo papel fundamental na hermenêutica da formas e símbolos da linguagem carnavalizada. As imagens referentes ao princípio da vida material e corporal em Rabelais, bem como em vários outros autores renascentistas, como Boccaccio, Shakespeare, Cervantes, em menor escala, são tributárias da comicidade popular, de uma concepção estética da vida ordinária. A isso, Bakhtin denomina de realismo grotesco (Bakhtin, 1993, p. 17).

No realismo grotesco do sistema de imagens da cultura cômica popular, a grosseria do princípio material e corporal manifesta um caráter positivo e afirmativo na sua universalidade, ludicidade e utopia. Quem parti- 
cipa da festa não é o indivíduo biológico isolado, nem o indivíduo egoísta burguês, mas o povo. A centralidade das imagens da vida corporal e material está na fertilidade, no crescimento e na abundância, o que irá determinar o caráter alegre e festivo (fuga da rotina) das imagens referentes à vida material e corporal. É o princípio da festa, do banquete, da alegria, das folganças e festanças típicas do período carnavalesco ${ }^{13}$.

Bakhtin aponta o rebaixamento como o traço marcante do realismo grotesco, ou seja, a transposição, aquela transgressão simbólica, de tudo o que é elevado e sublime, para o plano material e corporal, na concretude da terra e do corpo biológico, na sua indissolúvel unidade. Referindo-se a certos diálogos cômicos da Coena Cypriani, muito populares na Idade Média, Bakhtin cita os de Salomão com o bufão Marcul. De um lado, as máximas salomônicas, graves e elevadas, de outro, as tiradas jocosas e rasteiras do bufão, sempre direcionadas ao mundo material (bebida, comida, digestão, vida sexual).

Nesses procedimentos de interversão muito comuns na época, os bobos da corte rebaixavam as cerimônias de iniciação dos cavaleiros e outros ritos solenes. O rebaixamento do cerimonial cavalheiresco presente em Dom Quixote é inspirado na tradição do realismo grotesco ${ }^{14}$.

A inversão do sublime possui uma figuração tópica. O "alto" e o "baixo" possuem um sentido rigorosamente previsível. O "alto" situa-se no céu, o "baixo" na terra. Esta é, ao mesmo tempo, solo onde se enterra e se planta. Daí o sentido da terra conotar uma ambivalência: constitui princípio de absorção (túmulo, ventre) e de nascimento e ressurreição (seio materno). Essa dimensão tópica revela seu aspecto cósmico. Na sua dimensão corporal, articulada à dimensão cósmica, o alto é representado pela cabeça/rosto, e o baixo pelo sexo, o ventre e o traseiro. Esses pares bissêmicos são traços fortes do realismo paródico-grotesco medieval. Ouvem-se aqui os ecos do mito da Fênix. "Rebaixar consiste em aproximar da terra, entrar em comunhão com a terra concebida como um princípio de absorção mas também, de nascimento: quando se degrada, amortalha-se e semeia-se simultaneamente, mata-se e dá-se a vida em seguida, mais e melhor (.) degradação cava o túmulo corporal para dar lugar a um novo nascimento (.) o baixo é sempre o começo" (Bakhtin, 1993, p. 19).

Parece-nos eterno esse jogo pendular de inversões entre o sagrado e o profano, o sublime e o vagabundo, o "alto" espiritual e o "baixo" terra-aterra. Podemos, por exemplo, observar o que ocorreu com a música antiga. As escalas modais gregas, matrizes dos modos cristãos medievais (cantochão, escala ocidental maior - modo jônico, escala menor - modo eólio), tinham como princípio uma nota aguda, situada no alto. Assim, as escalas, ao serem executadas, realizavam um movimento descendente. Os monges medievais conservaram as mesmas ordens escalares, invertendo, porém, essa dinâmica descendente. As trajetórias dos modos cristãos passaram a ter como ponto de partida uma nota básica grave situada na parte baixa da escala, desenvolvendo percursos ascendentes. Tal inversão nos permite a seguinte reflexão: não teria 
a ascese cristã medieval intervertido o mundo mítico-ritualístico grego? Não eram os deuses gregos antropomorfizados, com desejos, paixões, iras, ciúmes e prazeres? Deuses que descem do Olimpo para se regozijarem nas festas dos humanos, ao contrário do mundo religioso judaico-cristão, que concebe o homem como criatura feita à imagem e semelhança de seu criador, mas que perde a inocência ao comer o fruto proibido e, por isso, é expulso do paraíso? Portanto um ser em permanente luta para superar sua condição de terreno, que busca sempre ascender à perfeição celestial?

A paródia renascentista conserva as melhores tradições da cultura carnavalesca popular, figurando em Rabelais, sua expressão mais perfeita e profunda. Já em Cervantes, Bakhtin vê alterações do sentido do princípio material e corporal, bem como atenuações do seu naturalismo e do seu caráter festivo, reflexão que nos cabe, nos limites deste trabalho, apenas mencionar.

Interessa-nos aqui destacar a manutenção dos traços profundamente carnavalescos em D. Quixote. O apetite e a sede do grande ventre de Sancho Pança, alegoria recorrente à dimensão glutônica da festa, retratam sua inclinação para a mesa farta e generosa, sem caráter egoísta e pessoal, mas, pelo contrário, uma inclinação para a fartura geral. Sancho seria um herdeiro direto da linhagem dos antigos demônios pançudos da fertilidade, a exemplo do que se vê nos vasos coríntios. O naturalismo grotesco da pança de Sancho seria o ventre acolhedor do idealismo abstrato, particular e insensível de Dom Quixote. Quixote/Sancho, par antinômico que configura o mesmo jogo de espelho de imagens opostas, presente nas paródias medievais diante das idéias e ritos espirituais elevados; no papel do bufão diante das cerimônias solenes; do carnaval e da Charnage (período em que é liberado o consumo de carne) em relação à Quaresma. O terra-a-terra sancheano (princípio do material e do corporal) é transmutado nas brumas oníricas da visão anacrônica de Dom Quixote. Em vez de moinhos de vento, vêem-se gigantes a combater; em vez de toscos albergues, castelos fortificados; em vez de rebanhos de dóceis animais, exércitos de cavaleiros; em vez de estalajadeiros, castelãs; em vez de prostitutas, damas da corte ${ }^{15}$.

Muito embora identifique inflexão de perspectiva no texto de Cervantes, Bakhtin afirma a fidelidade da literatura renascentista a uma profunda visão carnavalesca do mundo, cujo realismo agora é produto da articulação da herança da cultura cômica popular com a típica visão da existência fragmentada do novo homem da sociedade burguesa moderna. Assim, o realismo renascentista executaria um movimento pendular entre essas duas linhas contraditórias. Fragmentos e vestígios do realismo grotesco estariam também presentes no campo da literatura realista ocidental dos últimos séculos, cuja vitalidade, de tempos em tempos, é resgatada, sem no entanto recuperar, na maioria dos casos, sua força positiva.

O realismo grotesco caracteriza um fenômeno em permanente transformação, metamorfose sempre precária e provisória, estado de morte e nascimento. Tempo e evolução são condições possibilitadoras da constituição 
da imagem grotesca. Outra condição indispensável articulada às anteriores é a sua ambivalência.

As imagens grotescas, com sua rica ambivalência, irrompem, no Renascimento, como a expressão artística e ideológica, por excelência, de um vigoroso sentimento da história e de sua alternância. Eis a chave histórica para a compreensão da narrativa rabelaisiana. As imagens do realismo renascentista conservam o grotesco original, afastando-se das imagens da vida cotidiana, inspiradas numa estética preestabelecida. Ambivalentes e contraditórias, aparentam monstruosidade e disformidade, contraponteando com a estética "clássica" do Renascimento. "A nova percepção histórica que as trespassa, confere-lhes um sentido diferente, embora conservando seu conteúdo e matéria tradicional: o coito, a gravidez, o parto, o crescimento corporal, a velhice, a desagregação e o despedaçamento corporal, etc., com toda a sua materialidade imediata, continuam sendo os elementos fundamentais do sistema de imagens grotescas. São imagens que se opõem às imagens clássicas do corpo humano acabado, perfeito e em plena maturidade, depurado das escórias do nascimento e do desenvolvimento" (Bakhtin, 1993, p. 22).

Para ilustrar tal fenômeno, Bakhtin nos remete às velhas grávidas modeladas em terracota de Kertch, no Museu l'Ermitage de Leningrado, onde a velhice e a gravidez são grotescamente representadas. Nada acabado, perfeito ou estável no corpo das velhas. "Combinam-se ali o corpo descomposto e disforme da velhice e o corpo ainda embrionário da nova vida. A vida se revela no seu processo ambivalente, interiormente contraditório (.) é a quintessência da incompletude" (Bakhtin, 1993, p. 23) ${ }^{16}$.

O caráter constitutivo mais forte da carnavalização da vida e do mundo, com maior pertinência para a "identidade cultural" brasileira, referese ao mundo das transgressões e das interversões. Instaurando uma visão não rotinizada do mundo e da vida, a festa do congraçamento pagão, do "mundo às avessas" significa liberação, inversão de hierarquias, papéis, regras, valores etc. Rito do rebaixamento, inverte-se o "alto" e o "baixo".

Na festa brasileira, são várias as ocorrências do "mundo ao revés": troca-se o dia pela noite, a vida do bairro pelo centro da cidade, o território do trabalho e da fadiga dá lugar para o território da dança e do prazer. Trocam-se os papéis sexuais e sociais - homens machistas vestem-se de mulher, adultos usam fraldas e chupetas, cantam "mamãe eu quero mamar"; homens graves fantasiam-se de malandro; negros e brancos fantasiam-se de índios; pobres vestem-se de aristocratas; pessoas da classe média vestem-se de "sujos"; animados foliões cobrem-se com mortalhas ${ }^{17}$.

Ao reconstruirmos sinteticamente o conceito de carnavalização de Bakhtin não pretendemos "formatar" uma categoria a ser aplicada rigidamente nas ocorrências carnavalescas, tão típicas nas práticas culturais do povo brasileiro, bem como na produção intelectual de artistas brasileiros. Lembremos que um dos atributos fundamentais da concepção carnavalizada é a ambivalência e a ambigüidade. Portanto, ao reconstruí-la como categoria, exige- 
se necessariamente flexibilização metodológica ao confrontá-la com a faticidade empírica. Temos também de levar em conta que o grotesco popular, na contemporaneidade, foi re-estetizado pela indústria cultural, subsumido à lógica da mercadoria, desqualificando-o e exacerbando a quebra da unidade do sentido ambivalente do rebaixamento positivo da carnavalização medieval, cujo esmaecimento provocado pelo realismo renascentista já havia sido detectado pelo próprio Bakhtin.

Nossa intenção é examinar como o fenômeno da carnavalização, tendo Bakhtin como importante suporte de estratégia analítica, se manifesta em dois momentos importantes de nossa vida cultural: o antropofagismo e o tropicalismo.

Esses momentos radicalizantes da visão carnavalizada da vida e do mundo reiteram, a rigor, um traço já encontrado em vários outros momentos da história de nossas práticas culturais, desde o início da colonização. Segundo o historiador da vida e obra dos jesuítas no Brasil, pe. Serafim Leite, os primeiros contatos com os nativos foram possíveis graças à “ "música de caráter exclusivamente popular no gênero de folia, (...) a que se não deve atribuir nenhum caráter religioso, mas de simples e honesta diversão popular' "'(apud Tinhorão, 1990, p. 36). O apelo a algumas práticas prefiguradoras da carnavalização era tão forte que Anchieta, ao mesmo tempo que dava espaço para o imaginário popular se manifestar "em cantigas profanas que andavam em uso", fornecendo "novas letras de assunto pio", ele próprio combatia a possibilidade de profanação dos rituais religiosos (cf. pe. Simão Vasconcelos, apud Tinhorão, 1990, p. 37).

A presença das festas populares nas manifestações religiosas já era tradicional em Portugal: nos autos pastoris, os atores dançavam "ao som da viola, pandeiro, e tamboril e frauta [sic], e juntamente representavam um breve diálogo cantando algumas cantigas pastoris" (Tinhorão, 1990, p. 37). Essa herança popular das encenações natalinas festivas, no Brasil, migra da Bahia para o Rio de Janeiro, originando os ternos e ranchos de Reis, até sua completa paganização, como veremos adiante, em fins do século XIX, quando dariam origem aos ranchos de Carnaval, "cuja estrutura passaria, afinal, com suas alegorias e enredos, às escolas de samba” (Tinhorão, 1990, p. 38).

Os termos folia e folião parecem transitar naturalmente em várias práticas populares festivas. Podem se referir tanto à folia dos Santos Reis ou folia do Divino como à folia pagã do carnaval. A visão carnavalizada do povo não poupa nem o Espírito Santo, pois este, visto como um folião glutão, parece compartilhar "do apetite e da sede do grande ventre de Sancho Pança", conforme atesta Manuel Antonio de Almeida, em Memórias de um sargento de milícias, ao narrar uma Folia do Divino, no Rio oitocentista, onde pastores "colhendo esmolas de porta em porta" entoavam a seguinte cantiga: 
O Divino Espírito Santo

É um grande folião,

Amigo de muita carne,

Muito vinho e muito pão

(apud Tinhorão, 1990, p. 131).

A suprema carnavalização da festa de origem profano-religiosa darse-á em fins do século XIX, quando o baiano Hilário Jovino decide sair com o seu rancho no Carnaval, não no natal como de costume, obtendo um grande sucesso, graças à sua boa organização e à presença feminina. Além dessa novidade, uma das mulheres, prefigurando a porta-bandeira das Escolas de Samba, ia à frente com um belo estandarte. Todo esse processo de carnavalização se completa, considerando que o estandarte fora "encomendado por Hilário à Casa Sucena, especializada em paramentos de igreja e artigos religiosos em geral"* (Tinhorão, 1990, p. 213).

\title{
Carnavalização à brasileira
}

\section{Antropofagia e modernismo de Oswald de Andrade}

\author{
Tupi or not tupi that is the question. \\ Ante dos portugueses descobrirem o Brasil, \\ o Brasil tinha descoberto a felicidade. \\ A alegria é a prova dos nove. \\ (Fragmentos do Manifesto Antropófago, \\ Oswald de Andrade) \\ O carnaval no Rio é o acontecimento religioso da \\ raça.Pau-brasil. Wagner submerge ante os cordões \\ de Botafogo. \\ A cozinha. O vatapá, o ouro e a dança. \\ (Manifesto da Poesia Pau-Brasil, Oswald de Andrade) \\ Quem foi que inventou o Brasil? \\ Foi seu Cabral, foi seu Cabral. \\ No dia 21 de Abril, \\ Dois meses depois do carnaval. \\ (Lamartine Babo)
}

Para Boaventura Santos, "ao declarar os poemas reunidos na coletânea Pau Brasil, publicada em 1924, como tendo sido escritos 'por ocasião da descoberta do Brasil', Andrade propõe-nos um começo radical" (Santos, 1995, p. 136), da mesma forma como sugere a marchinha de Lamartine Babo, que, mesmo não pertencendo ao movimento antropofágico, partilha da visão análoga que inventa a festa carnavalesca e a alegria - a prova dos nove -, antes da descoberta do país pelos portugueses. O movimento antropofágico, 
ao invés de excluir o outro, propõe devorar "o tempo que o precede, seja o tempo falsamente primordial do nativismo brasileiro, seja o tempo artificialmente universal do eurocentrismo" (Santos, 1995, p. 136). Tempo fundador de uma sociabilidade outra, que nega seu negador, sem buscar sua anulação. Tal perspectiva leva-o a recusar a "macumba para turista", bem como a instaurar um novo tempo iniciático de criação cultural, onde o genuinamente brasileiro significa que tudo pode ser estética e festivamente reaproveitado.

Os manifestos oswaldianos, como boa parte do modernismo dos anos 20, procuram se livrar de um pesado fardo proveniente de uma tradição beletrista, considerada estéril, da cultura nacional. A radicalidade da proposta antropofágica poder ser aferida pelo ataque feroz que sua poética desfere contra os "epígonos do parnasianismo", um Brasil visto pelos "mitos do bem dizer", onde triunfava o "patriotismo ornamental", no dizer de Antônio Cândido. Por ocasião da irrupção da Semana de Arte Moderna de 22, "Rui Barbosa, 'a águia de Haia' ", Coelho Neto, o 'último heleno', Olavo Bilac, ‘o príncipe dos poetas', eram os deuses incontestes de um Olimpo oficial, no qual o Pégaso parnasiano arrastava seu pesado caparazão metrificante e a riqueza vocabular (entendida num sentido meramente cumulativo) era uma espécie de termômetro da consciência 'ilustrada' " (Campos, 1990, p. 8). É sobretudo, contra o parnasianismo que Oswald de Andrade assesta sua metralhadora giratória ao fazer a defesa da : "língua sem arcaísmo, sem erudição. Natural e neológica. A contribuição milionária de todos os erros. Como falamos. Como somos... Só não se inventou uma máquina de fazer versos - havia o poeta parnasiano" (Andrade, 1990b, p. 42 ss) ${ }^{18}$. Os que reagem à nova poesia, são estigmatizados com o epíteto de "poetas do Diário Oficial".

A exigência de novos postulados estéticos para a linguagem artística é, para Andrade, decorrência imperiosa de um esprit nouveau da época, por ele captado, tanto quanto o tropicalismo foi capaz de captar um novo Zeitgeist, algumas décadas mais tarde. É nítida a contribuição recebida dos modernistas, sobretudo do dadaísmo.

Ver com olhos livres (Oswald de Andrade). A voracidade da estética antropofágica desenvolve uma dialética desconstrutivista/reconstrutivista, o que foi assinalado por Paulo Prado no prefácio escrito em 1924 para o poema de Andrade, texto que mais parece ser um manifesto sobre o Manifesto PauBrasil. "A poesia 'pau-brasil' é, entre nós, o primeiro esforço organizado para a libertação do verso brasileiro (.) um período de construção criadora sucede agora às lutas da época de destruição revolucionária, das 'palavras em liberdade' (...). Sejamos agora de novo, no cumprimento de uma missão étnica e protetora, jacobinamente brasileiros. Libertemo-nos das influências nefastas das velhas civilizações em decadência (...). Esperemos também que a poesia 'pau-brasil' extermine de vez um dos grandes males da raça - o mal da eloqüência balofa e roçagante" (Prado, 1990, p. 58 ss). A cabeça antropofágica é 
como a cabeça de Juno, de duas faces. Uma, a que dessacraliza, é desconstrutiva. A outra, a que rearticula os materiais anteriormente desierarquizados e devorados/reinventados e reapropriados, é reconstrutiva.

Para Andrade, a nova linguagem poética possui bases sólidas na nova era industrial. Prefigura-se o desafio que uma arte, desauratizada pela indústria cultural, enfrentará a partir dos novos tempos. O dado novo precisa ser canibalizado. "Houve um fenômeno de democratização estética nas cinco partes sábias do mundo (...). Veio a pirogravura. As meninas de todos os lares ficaram artistas (...). Apareceu a máquina fotográfica. E com todas as prerrogativas do cabelo grande, da caspa e da misteriosa genialidade de olho virado o artista fotógrafo. Na música, o piano invadiu as saletas nuas, de folhinha na parede. Todas as meninas ficaram pianistas. Surgiu o piano de manivela, o piano de patas. A pleyela. E a ironia eslava compôs para a pleyela. Stravinski. A estatuária andou atrás. As procissões saíram novinhas das fábricas" (Andrade, 1990b, p. 42).

Mas talvez o novo dado tecnológico a jogar um papel fundamental na linguagem antropofágica, via dadaísmo e outras expressões do modernismo europeu, tenha sido o cinema, com sua linguagem fragmentada, com a montagem de imagens múltiplas, com a velocidade de um tempo elidido, com o abandono da idéia de "ilusão da realidade", e de um nova arte sujeita a seus próprios e novíssimos cânones. Em termos de proposição de novos postulados e paradigmas estéticos, o cinema está para o antropofagismo assim como a televisão estará, mais tarde, para o tropicalismo.

Nossa reflexão sobre o antropofagismo estaria incompleta se não abordássemos, ainda que sumariamente, a questão da concepção oswaldiana acerca do regionalismo e do nativismo indigenista. "Ser regional e puro em sua época". Andrade rejeita proclamações regionalistas estreitas e exclusivistas. Antropofagismo significa tensão dialética entre o regional e o universal. Ser regional é ser brasileiro na contemporaneidade universal. Mais uma vez o modelo dadaísta, no imaginário antropofágico: o movimento europeu exercia uma função crítica dessacralizante de contestação à arte aurática elitista e excludente. $\mathrm{O}$ triunfo da civilização tecnológica reveste-se de condições possibilitadoras da democratização dos bens culturais. No caso brasileiro, aquela função crítica possuía mais um front de combate - a consciência beletrista estéril, enraizada na ancestralidade bacharelesca e na mentalidade dos jurisconsultos das tertúlias de salão, expressão de uma cultura livresca radicada numa economia atrasada agro-exportadora. Essa postura não podia escapar das presas antropofágicas. Como qualquer outro motivo de deglutição, era devorada e reinventariada numa nova perspectiva.

Outro solo tropical bastante fértil onde o antropofagismo também vicejou foi o do embate travado no interior do próprio movimento modernista. Em 1926, as propostas mais radicais do movimento de Andrade sofreram um processo de diluição, com fortes traços de adernamento conservador. Essa versão edulcorada recebeu o nome de "verdamarelismo", liderada pelos 
escritores Plínio Salgado e Mennotti del Pichia, futuros participantes do Integralismo. "O anarquismo revolucionário de Oswald vira, no documento 'verdamarelo', conservantismo prudente e cheio de indefinições" (Campos, 1990, p. 43). O indianismo "verdamarelo" confunde-se com o "ufanismo" do Conde Afonso Celso. É o próprio poeta Cassiano Ricardo, integrante daquela versão diluída, que confessará mais tarde: "do grupo verdamarelo nascem o Integralismo e a Bandeira. E pronto” (Campos, 1990, p. 43). Contra o "verdamarelismo", Oswald irá cunhar a famosa frase, muito reverenciada pela Tropicália: "triste xenofobia que acabou numa macumba para turista". Indignando-se contra o ufanismo indigenista, o mito da "raça de gigantes", Andrade brada seu Manifesto Antropófago: "Contra o índio de tocheiro. O índio filho de Maria, afilhado de Catarina de Médicis e genro de D. Antônio de Mariz" (Campos, 1990, p. 44). Ao "bon sauvage" de Rousseau, aclimatado por José de Alencar e Gonçalves Dias, contrapõe o “mau selvagem”, o canibal de Montaigne, para devorar as imposturas do civilizado.

\section{Oswald de Andrade}

\section{Em Piratininga Ano 374 da Deglutição do Bispo Sardinha}

Assim assina, localiza e data o poeta seu manifesto.

\section{A retomada da linha antropofágica pelo tropicalismo}

A redescoberta do antropofagismo oswaldiano foi um passo natural na curta trajetória da Tropicália. O tributo a Andrade é explícito na entrevista do próprio Caetano concedida a Augusto de Campos, com a participação de Gil: “o Tropicalismo é um neo-Antropofagismo” (Campos, 1978, p. 207). É nítida a filiação oswaldiana da frase de Caetano que diz: "nego-me a folclorizar meu subdesenvolvimento, para compensar as dificuldades técnicas" (Campos, 1978, p. 285). A estética antropofágica significa devorar, digerir, vomitar. A Tropicália rompe com o discurso explicitamente político para concentrar-se numa atitude iniciática primitiva, que põe de lado o discurso unívoco sobre a realidade nacional, passando a ver o Brasil a partir de vários olhares. O ver com os olhos livres oswaldiano assume agora a perspectiva multifacética de vários olhos livres bem como de um ouvir através de vários ouvidos livres.

Para o Tropicalismo, o outro não deve ser anulado. Operando um descentramento cultural e valorativo multiperspectivista, pela articulação de múltiplas falas e olhares, contrário aos discursos que antes tomavam univocamente a realidade nacional, e pelo aproveitamento das manifestações estéticas de várias proveniências, a Tropicália configura um novo material, uma "obra aberta" de múltiplas significações. As contradições de uma "contemporaneidade não coetânea" não são objeto de mera denúncia, mas suas ambigüidades ou ambivalências são incorporadas na obra, na nova forma artística. O arcaico e o moderno, o rural e o urbano-industrial, o cafona e o bom-gosto, o biscoito fino e a massa grossa, a arte alienada e a engajada, o público e o privado, o experimentalismo e a participação, a "bossa" e a "roça", 
a informação e a redundância, qualquer antinomia, política ou estética, é elidida em nome do direito à alteridade e da integração antropofágica do material que é deglutido no mesmo instante em que é inventariado. "Os efeitos da crítica cultural e da inovação artística são assim produzidos por apropriações e montagens, agenciando paródia e alegorização na construção de imagens" (Favaretto, 1988, p. 21).

Verifica-se o mesmo procedimento referente às manifestações políticas, culturais, artísticas ou tecnológicas provenientes do exterior, ora merecendo citações aparentemente "neutras", ora tensionando e exacerbando a intensidade musical da canção tropicalista. Daí a constante auto e heteroreferência no Tropicalismo. A citação é um dos seus recursos estéticos preferidos. Reinterpreta-se tudo. De Lupiscínio Rodrigues a Chico Buarque, passando por Vicente Celestino e Roberto Carlos, bem como por Frank Sinatra, Lucho Gatica e Paul Anka.

\section{O surgimento do Tropicalismo}

Em meados dos anos 60, a MPB entrava em profunda crise ${ }^{19}$. A Revista da Civilização Brasileira promove em 1966 um debate com a participação, entre outros, de Caetano Veloso e Capinam, Nara Leão e o poeta Ferreira Gullar, na época, o mais alinhado à estética inspirada no realismo socialista do Centro Popular de Cultura (CPC), da UNE. Caetano profere então uma frase que iria se tornar famosa e recorrente para muitos analistas da MPB - a necessidade de retomar a linha evolutiva deixada por João Gilberto ${ }^{20}$, como forma de sair do impasse em que se encontrava a nossa música.

Antes de prosseguir, gostaríamos de mencionar uma impropriedade contida na expressão linha evolutiva cunhada por Caetano, à qual aderem acriticamente analistas e/ou músicos da nossa MPB, como Augusto Campos, Júlio Medaglia, Gilberto Gil. O próprio Favaretto incorre na impropriedade, a despeito do belo livro que escreveu sobre o movimento, do qual este nosso trabalho se sente devedor. Levando em conta as propostas que aos poucos foram se configurando no interior do movimento, veremos que o Tropicalismo, como tributário da visão carnavalizada do mundo, propõe-se a ser paródia do mundo oficial e sério, reinventariando tudo que lhe antecede. Daí sua proposta multiperspectivista e multivalorativista.

A expressão linha evolutiva da MPB conota o sentido de evolução nas artes. Subjaz a essa concepção evolucionista a idéia de um processo valorativo onde algo se movimenta de um ponto inferior a outro superior: um menos que evolui para um mais, um menor para um maior, um algo menos qualificado para algo melhor. Sua adoção no campo da estética é bastante complicada, uma vez que esse "algo mais" poderia ser traduzido como "mais qualidade", portanto, mais arte, mais forma, mais desenvolvimento estético, mais "finesse". Recai-se assim numa atitude uno-perspectivista e valorativista, onde o evoluído torna-se superior ao que lhe antecede. E foi também contra tudo isso que o Tropicalismo se insurgiu, um ano e meio depois do debate da 
RCB, para sacudir o mundo musical do país.

Segundo Tom Zé, o Tropicalismo foi um movimento bem datado: durou um ano e dois meses. Para sermos exato, de outubro de 67 [ $3^{\circ}$ Festival da MPB da Record] a dezembro de 1968 [prisão de Caetano e Gil, logo após o AI-5, promulgado pela ditadura militar]. Segundo R. Duarte, músico e produtor gráfico da capa do disco Tropicália, não se tratou de um movimento, mas de um momento de um movimento maior que começara antes. Movimento ou não, qual a razão de sua força, expressando um tipo de fenômeno que tanto tem atraído a atenção de pensadores da cultura e da política, onde anos parecem estar condensados em frações mínimas de tempo, provocando profundas rupturas, liberando um magma desconstrutor e reconstrutor, abrindo novas perspectivas e infinitas possibilidades de criação, nos mais diferentes domínios da ação humana? O Tropicalismo parece ter sido portador dessa força.

Caetano e Gil são enfáticos: o Tropicalismo não surge como movimento organizado. Ele é fruto da preocupação entusiasmada com a discussão e proposta de algo novo, como forma de enfrentar a crise vivenciada pela MPB. Em outubro de 67, quando Domingo no parque e Alegria alegria eclodem no Festival da Record, em SP, esse algo de novo ocorre, na área musical, aportando um debate no mesmo nível que vinha ocorrendo em outras modalidades da cultura brasileira: artes plásticas, cinema, teatro e literatura. Será essa articulação que dará consistência ao que mais tarde será designado de Tropicália ou Tropicalismo.

O que caracterizou o final da década de 60, no mundo ocidental, foi a radicalidade crítica do movimento da chamada Nova Esquerda, que explicita questionamentos à militância política ortodoxa e tradicional, emblematicamente representada pelos Partidos Comunistas ainda presos ao ranço estalinista, bem como e sobretudo pelas novas propostas estéticas, rejeitando categoricamente subsumir a criação artística aos ditames conteudísticos dos propósitos revolucionários, como critério de qualidade da obra de arte. "Imaginação no poder", palavra de ordem de maio de 68 da revolta estudantil na França, bem poderia ser traduzida como reinventar a política pela estética.

No Brasil, o social-realismo do CPC, com forte influência do ISEB ${ }^{21}$, era a expressão exacerbada da politização da estética. A nova esquerda propõe estetizar a política: Maio de 68, movimento da contracultura, guerra do Vietnã, "Revolução na Revolução", guerrilha latino-americana, Guevara. E mais: TV, indústria cultural, rock internacional e jovem guarda, cinema francês (leia-se Godard), psicodelismo, drogas, elevação do padrão de consumo de setores restritos porém de altíssimo poder aquisitivo das novas camadas médias brasileiras (leia-se "milagre brasileiro" dos magos da economia da ditadura militar), pressão consumista comandada pela sedução midiática, postulação de novas posturas estéticas. Nesse turbilhão todo, no olho do furacão, um grupo de baianos (os baiunos, na visão preconceituosa do irreverente jornal carioca O Pasquim - os “doces bárbaros" que amavam a bossa nova, os Beatles e os Rolling Stones) capta esse novo Zeitgeist. Não aquele “espírito do tempo" 
único e necessário, fruto da odisséia do espírito absoluto hegeliano, mas l'esprit nouveau capaz de dar conta da multiplicidade polifônica de um sensibilidade outra trazida pelos novos tempos.

Com radicalidade, o tropicalismo propõe a efetivação da modernidade artística, prefigurada na proposta antropofágica, por meio da compreensão singular das variadas interpretações da realidade nacional, e não de uma única e hipostasiada realidade brasileira, e pelo rico tratamento das diferentes dimensões heterocrônicas de nossa realidade cultural. À visão unoidentitária, a proposta multidentitária. À mesmidade, a multialteridade. Assim, se nega a dar continuidade ao discurso perspectivista anterior, expresso numa verticalidade estética emanada das consciências politizadas que iam às massas alienadas, para proferir um discurso salvador, anunciador do novo dia que virá. No lugar dessa perspectiva da decolagem revolucionária, a estética da colagem (ou da bricolagem), da horizontalidade do tudo, ao mesmo tempo, agora, do tutto e subito.

Segundo Celso Favaretto, ao mesmo tempo que o tropicalismo "articulava uma nova linguagem da canção, a partir da tradição da música popular brasileira, e dos elementos que a modernização fornecia, sua intervenção configurou-se como um trabalho de desarticulação das ideologias que, nas diversas áreas artísticas, figuravam a relação entre experimentalismo estético e participação social" (Favaretto, 1988, p. 20). Assim, o tropicalismo procura dar uma resposta desconcertante na discussão sobre as relações entre política e arte.

Examinemos duas obras fundadoras da Tropicália, apresentadas no festival da Record. Alegria, alegria, de Caetano Veloso, inova na medida em que usa procedimentos narrativos e musicais até então estranhos à tradição da MPB - a colagem icônica de um mundo estilhaçado veiculado por manchetes condensadas e crispadas, pela estética veloz da linguagem televisiva e da propaganda ${ }^{22}$. A canção de Caetano descreve os problemas sociais e políticos, nacionais ou internacionais, misturando-os ao cotidiano vivenciado por jovens de classe média, expurgando o caráter agressivo, típico do pathos da MPB engajada. A tranqüilidade do acompanhamento das guitarras elétricas dos Beat Boys (suprema heresia para os mais puristas) e da interpretação de Caetano reforçam o estranhamento de um público habituado a vibrar com canções denunciadora da miséria e anunciadoras de um novo dia. Ambígua, a canção intriga (cf. Favaretto, 1996, p. 18). A alusão ao uso de alucinógenos, camuflada no diagrama do verso sem Lenço e Sem Documento (LSD), inspirado na canção Lucy in the Sky of Diamonds, dos Beatles, do disco Sergeant Pepper's, lançado no ano anterior, irrita profundamente os que exigem dos artistas uma postura de combate radical à ditadura militar e de crítica explícita à alienação da juventude consumidora de drogas. A poética aparentemente neutra dos versos que falam de guerrilhas, bombas, crimes, fuzis, conotando o registro do seu lado político-social, não tem prevalência sobre Brigitte Bardot, a coca-cola, a canção da jovem guarda, as pernas ou Cardinales bonitas. Assim, 
prazer estético e crítica social parecem co-habitar. "Por que não? Por que não? Por que não?" desafia Caetano, com um sorriso provocativo.

Aconstrução de Domingo no parque (Gilberto Gil), fruto do arranjo de Rogério Duprat, radicada numa concepção cinematográfica eisensteiniana (cf. Campos, 1978, p. 154), reforça o tratamento de choque que a MPB experimentou naquela histórica noite da Record. A temática é similar à canção de Noel Rosa, Quando o samba acabou, narrativa trágica de um triângulo amoroso que se passa nas classes populares - uma mulher disputada por dois homens. A performance interpretativa de Gil, contraponteada pelos Mutantes, transforma-a numa espécie de vertigem feérica, onde a letra, a música e o cantar compõem uma cena de movimentos variados, numa festa sincrética do parque de diversões: letra, música, sons, palavras, gritos fundem-se nos ruídos de parque, nos instrumentos clássicos, junto com berimbau, guitarras elétricas, coral, procedimentos atonais justapostos aos tonais, configurando a canção de Gil como lídima expressão da carnavalização tropicalista associada ao canibalismo oswaldiano. Sons e imagens explodem numa cacofonia dissonante e polirrítmica, onde o rodopio acelerado da roda-gigante-girante provoca explicitamente uma intensidade vertiginosa, onde o sorvete-morango-vermelho na mão de Juliana confunde-se com a imagem da rosa-vermelha, fundindo-se no sangue-vermelho agora na mão de José, no corpo da amada Juliana e do amigo João.

Para Favaretto, Tropicália, de Caetano Veloso, é a música inaugural e matriz estética do movimento. A canção inicia-se no meio de um som baseado em escalas não tonais de instrumentos não temperados, portanto, estranho à tonalidade eurocêntrica - universo sonoro pré-cabralino - com uma declamação paródica da carta de Caminha, o escrivão-mor da esquadra de Cabral. Como na Poesia Pau-Brasil e na marchinha de Lamartine Babo, o Tropicalismo demarca, em tom de deboche, a data oficial da descoberta do país, diferentemente do tempo iniciático do país tropical, explicitando uma concepção carnavalizada. Talvez por ser o compositor com maior domínio da língua dentre os poetas do tropicalismo, Caetano parece brincar com as palavras. Essencializa o texto, na procura freqüente do isomorfismo entre o som e o sentido das palavras. Para Campos, o tropicalismo reabilita um gênero que parecia morto: a da poesia cantada, na melhor tradição dos trovadores provençais do motz el som, ou seja, a arte de combinar palavra e som. Pela transparência de sua linguagem, que não apenas "significa", mas também "soa", bem como pela reverberação da sonoridade de alguns fonemas e do uso reiterado de ricos recursos lingüísticos como paronomásias, onomatopéias e aliterações, no corpo da canção "viva a mata-ta-ta viva a mulata-ta-ta-ta-ta".

Caetano configura um painel histórico metafórico do país. Articula o desarticulado, presentifica dimensões heterocrônicas, convivendo o mais arcaico com o mais moderno: eventos, estereótipos, citações, jargões e emblemas, ruínas e fragmentos. Do planalto central, o poeta "organiza o movimento, orienta o carnaval”, inaugura um país outro, monumento sem 
porta, "feito de papel crepon e prata". Seu coração pulsa ao ritmo de um "samba de tamborim", emitindo "acordes dissonantes", assimétricos, assincrônicos. Tempo e fatos totalmente díspares, articulados numa temporalidade outra, neutra, via discurso quase nonsense, dessacralizam a narrativa oficial que transforma as disparidades histórico-culturais em "macumba para turista ver". "A música se realiza na alternância de festa e degradação, em carnavalização e descarnavalização, (...) agenciadas pela enumeração caótica das imagens na letra, entoação de Caetano e contraponto metalingüístico do arranjo de Júlio Medalha (...). A montagem é cubista, articulando imagens surrealistas, segundo um ritmo cinematográfico à maneira de Godard. A mistura é composta de ritmos populares brasileiros e estrangeiros (...), música clássica e de vanguarda, ritmos primitivos e Beatles, cancioneiro popular e poesia parnasiano: o bom gosto e o mau gosto, o fino e o grosso" (Favaretto, 1996, p. 56 ss). Costurando subliminarmente os refrãos, o pulso de um baião (cf. Campos, 1978, p. 163 ss).

\section{Tropicália: o disco manifesto}

O disco Tropicália ou Panis et circencis de 1968 representa uma síntese do projeto da estética tropicalista. Nele, alegoricamente, lá tudo está, tutto e subito: é neste disco onde se vislumbra, com toda a clareza, o processo de carnavalização, objeto de análise deste trabalho: a festa, a crítica musical e social, o rural-arcaico e o urbano-industrial, o kitsch popular e o "bom gosto" erudito, metáforas, o deboche, tudo isso consubstanciando a grande geléia geral brasileira, oferenda sacro-profana para ser devorada num ritual antropofágico. Projeto coletivo ${ }^{23}$, inclusive o arranjo, conforme depoimento do maestro Rogério Duprat, tudo no disco-manifesto é feito cuidadosamente.

A capa do disco é uma grande meta-representação. Segundo Favaretto, é uma síntese globalizante, espécie de programa visual do que será apresentado de forma fragmentada, onde seus integrantes assumem uma pose patriarcal das fotos antigas, contrastando com roupas e instrumentos modernos, e a citação explícita ao famoso urinol - Fonte de 1917 - ready-made de Marcel Duchamp, através do ar grave e solene do maestro empunhando o prosaico vasilhame como se fosse uma xícara de chá. O décor tropicalista é completado com o ambiente de um casa burguesa com tudo que tem direito: jardim interno com palmeira, vitral, banco de pracinha do interior, emoldurados em cor anil-verde-amarela, deixando entrever uma alusão irônica ao "verdamarelismo", aquela vertente direitista do movimento modernista combatida por Oswald de Andrade.

O disco, concebido como uma espécie de suíte, revela um dos atributos mais definidores da concepção carnavalizada do mundo e da vida, a dualidade da visão popular de que fala Bakhtin. O ciclo percorrido pelas canções cumpre uma espécie de rito, onde a marca carnavalizante da alternância entre o sagrado e o profano está sempre presente, como se a celebração oficial e a paródia fizessem parte do mesmo rito. Muitas vezes, a linguagem 
oficial parece ser a sua própria paródia.

Duas canções extraídas da porção sagrada do disco abrem e fecham o ciclo tropicalista. O clima religioso do som de um órgão e de uma campainha usada na liturgia católica transmite uma sensação de culpa e contrição: miserere nobis, ora ora pro nobis. Migrantes calados, magros e famintos, na espera das sobras da janta, sonham com a utopia popular carnavalesca, de um dia partilhar de um banquete farto com "muita carne, muito vinho e muito pão": "tomara que um dia um dia seja, para todos e sempre a mesma cerveja (...) para todos e sempre metade do pão (...) na mesa da gente tem banana e feijão". A censura militar vivenciada na época é ludibriada pela forma oblíqua de denunciar a violência pela desconstrução fonêmica de três palavras-chave da canção: Brasil, fuzil e canhão. Tiros de canhão finalizam a música, prolongando-se na faixa seguinte, na canção Coração Materno, buscando aquela unidade estrutural da forma suíte.

O ciclo se fecha com outro signo ritualístico-religioso-festivo, o Hino ao Senhor do Bonfim. Se na abertura o Miserere nobis conotava culpa e contrição, agora temos festa e confiança, a despeito de vozes tonais reconstruídas numa dissonância aleatória, no meio do som de outros tiros de canhão misturados à explosão festiva de rojões. Para Favaretto, na visão tropicalista, a festa do Bonfim se transveste em efeméride oficial, transformada em "macumba para turista'. Na travessia desse ciclo ritualístico-religioso, um outro rito profano-pagão - a festa carnavalizada dos trópicos exposta em várias canções. Essa marcação temporal do disco, simultaneamente nítida e ambígua, visível e opaca, entre o sagrado e o profano, o religioso e o pagão, nos sugere uma reflexão bastante interessante.

Quando falamos do movimento pendular entre o divino e o humano, entre o sublime e o grotesco, além da obra de Bakhtin, tínhamos em mente o que hoje ocorre no carnaval de Salvador, onde o sagrado parece querer refazer seu caminho de volta, supra-assumindo agora o lado profano do rito.

Oficialmente, a festa deve ocorrer entre o domingo e a terça-feira que antecedem à quaresma, longo período de penitência e privações no calendário católico ${ }^{24}$. Na capital baiana, por volta do meio-dia da quarta-feira de cinzas, após vários dias de imensa folia, os mesmos trios elétricos animadores da festa pagã reúnem-se na praça para tocar, em uníssono, num clima de muita unção e recolhimento religiosos, como se estivessem no interior de uma igreja, o Hino ao Senhor do Bonfim (o mesmo da Tropicália) ou a Ave Maria de Gounod. A cena é bastante sugestiva: diferentemente da tradição católica, onde os fiéis vão às igrejas (alguns com algum confete na cabeça) para receber as cinzas num contexto religioso, milhares de foliões, permanecendo no mesmo cenário festivo-profano, vestidos com suas fantasias multicoloridas, extenuados e contritos, alguns chorando, ouvem as peças religiosas, executadas pelos mesmos músicos e instrumentos que tocaram as peças carnavalescas, como se naquele momento, constitutivo da mesma festa pagã, já iniciasse o período de recolhimento e penitência. Dessa forma, o 
sagrado e o profano parecem querer se fundir num mesmo rito, talvez numa vã tentativa de pós-figurar a restauração daquela unidade ritualística primordial e arcaica perdida, notada por Bakhtin ${ }^{25}$.

Examinemos mais de perto, as canções que julgamos principais do disco, pontuando algumas reflexões ${ }^{26}$.

Coração materno expressa a sentimentalidade de um tempo outro, de um lugar outro, de um Brasil rural-arcaico que, outrora, ouvia a voz empostada de Vicente Celestino, típica de cantores formados pelo bel-canto operístico, que a interpretava dramaticamente, nos circos do interior do país. Em Celestino, o discurso trágico era reiterado pela redundância do seu cantar trágico. A interpretação despojada e distanciada de Caetano Veloso, denotando quase um halo de reverência, ressalta-se como uma espécie de duplo, pelo avesso, da versão original. Ao contrário desta, na versão "cool" de Caetano, o pathos trágico não se situa no canto, quase uma récita neutra, sem sentimentalismos ou morbidez (malgrado toda a tragicidade da letra) ${ }^{27}$, mas no contraste do arranjo de Rogério Duprat que exacerba a tensão da canção, pelo uso quase que exclusivo das cordas, sobretudo dos violoncelos, em estocadas descendentes dos acordes graves quase-cromáticos, acentuando o clima trágico.

A canção Panis et circenses é outra alusão tropicalista ao onírico e às drogas da contracultura - "mandei plantar folhas de sonho [maconha] no jardim do solar" 28 -é grito de liberdade contra o ritual da família - "as pessoas na sala de jantar" - que não sofrem qualquer abalado - "são ocupadas em nascer e morrer". O domínio do privado, figurado na sala de jantar, é um cenário privilegiado da cena/ceia tropicalista. Em determinado momento, a canção é interrompida por uma processo de "desconstrução" eletroacústica, causada por uma aparente queda de energia. A música, ao ser retomada, é tencionada pelo ritmo que se acelera. Prossegue o banquete familiar-autofágico denotando esterilidade (diferentemente do ritual antropofágico, que é fecundo). A conversa se mantém. Ouve-se o ruído da louça que se quebra e, ao mesmo tempo, a voz de alguém que pede a salada. Outro comensal pede um pedaço. Fica a intenção da ambigüidade: o que é oferecido? $\mathrm{O}$ alimento partido ou a louça quebrada? Configura-se a "ordem "familiar que é mantida e o caos da louça que se quebra e dos ruídos de cacos de vidro (fragmentos da cultura nacional, inarticuláveis na cena/ceia autofágica familiar?). Como música de fundo, compondo a trilha sonora da cena/ceia familiar, o som erudito/popular de uma valsa de Strauss, logo sobrepujada pelo som eletroacústico realizando uma espécie de cromatismo ascendente, interrompido abruptamente, à moda das découpages cinematográficas da Nouvelle Vague do cinema francês, cuja estética é explicitamente reverenciada pelos tropicalistas.

Lindonéia é um bolerão inspirado no quadro homônimo ou também A Gioconda do subúrbio, do Rubens Gerchman, importante pintor participante do movimento tropicalista nas artes plásticas ${ }^{29}$. Nara Leão, intérprete da canção Lindonéia, comparece, na capa do disco, dentro da moldura de 
um quadro sustentado por Caetano, como se ela própria auto-meta-representasse uma Lindonéia outra. O clima melancólico da canção fala dos sonhos românticos de uma moça-suburbana-solitária-leitora de fotonovelas, que ouve rádio e vê televisão. Seu cotidiano, sem perspectivas, cercado de todo tipo de violência, a empurra para as "emoções baratas" das novelas. O jogo de espelhos revela um ilusionismo especular onde Lindonéia se vê "miss linda e feia", desaparecendo no seu avesso, para ressurgir no mundo romanesco onde, a seguir, se projeta. Versão tropical contemporânea de uma Madame Bovary às avessas, pois esta, no fim das contas, pratica o suicídio quando se vê impossibilitada de levar adiante suas fantasias, as evasões da Gioconda do subúrbio seriam talvez sua única saída para não tomar "formicida tatu" ou atear fogo às vestes, como o escritor Nelson Rodrigues gostava de caracterizar a forma predileta dos suicídios cometidos no subúrbio carioca.

O clima de deboche, na voz avacalhada dos vários intérpretes, é total no Parque industrial de Tom Zé aos mitos ufanistas brasileiros, a exemplo do orgulho típico do auto-deslumbramento do colonizado subdesenvolvido que se deleita em proferir frases do gênero "mais uma vez o mundo se curva perante o Brasil" ou "a Europa curvou-se perante o Brasil", conforme o título do poema de Oswald de Andrade ${ }^{30}$.É ataque feroz aos clichês da indústria cultural - "garotas-propaganda; aeromoças; cartaz; o sorriso engarrafado que já vem pronto e tabelado, made in Brazil". Sobressai a voz do músicocantor, Gilberto Gil, que conduz o espetáculo, à moda de quadrilha das festas juninas: "mais uma vez"; "vamos voltar". Na realidade, uma referência explícita à "pilantragem" comandada por Wilson Simonal, modismo oportunista traficado para o interior do ambiente musical daquele período, felizmente de curtíssima duração. A entonação avacalhada de Tom Zé, ao cantar a palavra Brazil, revela que não se deve levar a sério, o ufanismo-desenvolvimentista made in Brazil

Geléia geral de Gilberto Gil e Torquato Neto constitui, a nosso ver, autêntica suma tropicalista. Com rara felicidade, consegue expressar o "tudoao-mesmo-tempo-agora" da forma-conteúdo-da-estética-tropicalistaantropofágica da proposta do movimento. Tudo é devorado, deglutido e reinventariado, num processo permanente de desconstrução/reconstrução. $\mathrm{O}$ "poeta parnasiano do diário-oficial", em linguagem empolada, anuncia o paraíso tropical, numa manhã "resplandente candente fagueira", e o poeta cantor vai logo atrás e desmonta esse Brasil "para turista ver". "É bumba mês que foi; iê-iê-ano-que vêm". Tempos-lugares outros do ano que vem (futuro-jovem-iê-iê-iê) mês que foi (passado-arcaico-bumba-meu-boi). A letra do poeta-cantor desvela e articula temporalidades heterocrônicas. No meio da sala (uma vez mais o domínio do privado), todas os ícones da cultura nacional - "as relíquias do Brasil": as hipérboles do poeta maior do indianismo bom selvagem - Gonçalves Dias ("Minha terra onde o sol é mais limpo e Mangueira onde o samba é mais puro"), o Hino à Bandeira "Salve o lindo pendão dos teus olhos" e $O$ Guarani, Frank "all the way" Sinatra e a mulata, fruta santa e 
tropical barroco, Mangueira - estação primeira - e Portela, Carolina na janela, o Canecão (primeira mega-choperia do Rio, templo-ícone do lazer-classemédia-da-família-brasileira dos anos 60-70) e a TV.

Num carnaval de verdade ("acontecimento religioso da raça"), Gil contrapõe outras citações modernas, críticas, desconstrutoras, sobretudo de Oswald de Andrade. O carnaval antropofágico-tropicalista, ao se apropriar de mitos, práticas folclóricas, estilos, múltiplas citações, pretende ser uma espécie de signo paródico condensado da descolonização. Geléia geral é imersão profunda na metalinguagem. É o avesso do avesso. No limite, poder-se-ia configurar como uma espécie de poema-pastiche do pastiche feito por Andrade, nos poemas de abertura da Poesia Pau-Brasil. São poemas como que escritos pelo escrivão-mór da esquadra de Cabral, Pero Vaz de Caminha, de Gandavo, do francês Claude d'Abbeville, de Frei Vicente de Salvador, de Fernão Dias Paes e tantos outros. Como diz Favaretto: "Fica evidente nessa operação que, se o poeta oficial representa, o cantor representa a representação" (Favaretto, 1988, p. 96).

Três caravelas (Algueró Jr. e G. Moreu - versão de João de Barro), assim como Soy loco por ti América (Gil e Capinam) de outro disco, possível homenagem a Che Guevara, morto então recentemente nas selvas bolivianas ("el nombre del homem es muerto, el nombre del hombre es pueblo"), é declaração de fé e amor tropicalista à latino-americanidade, antigo sonho acalentado por Caetano: "o de criar uma música que integrasse toda a LatinoAmérica, com sua problemática comum. Tropicalismo anti-Monroe: a América para os Latino-Americanos" (Campos, 1978, p. 170). Se Lamartine Babo fixa o dia 21 de abril de 1500, "dois meses depois do carnaval", como data da invenção do Brasil, os tropicalistas, ao entoar a canção Três Caravelas, mix de vários ritmos e estilos latino-americanos, buscam recuar ainda mais o tempo de fundação do país. "O Brasil aconteceu” (inclusive o carnaval - "é o maior, que que há") porque "muita coisa sucedeu" depois que "um navegante atrevido salió de Palos un dia (...) hacia la tierra cubana. Viva Cristóvão Colombo, que para nossa alegria, veio com três caravelas, la Pinta, la Niña y la Santa Maria".

Utilizando-se da "inocência" de um conto infantil, a fábula de Chapeuzinho Vermelho, Caetano constrói a mais metafórica canção do disco. Enquanto seu Lobo não vem utiliza-se de um ritmo lento de samba-batucada, contraponteado, durante toda a música, por um insistente som de corneta e a repetição do refrão de Dorival Caimmi, "os clarins da banda militar”, na voz de Gal Costa, misturado com o som de agogôs, surdos e outros instrumentos percussivos, para falar do tempo vivenciado pelos brasileiros - tempo de medo. Burlando a repressão da ditadura militar, o poeta convida para um passeio político-libidinoso, às escondidas, "na floresta (...) por baixo da avenida (...) por debaixo das ruas, debaixo das bombas, das bandeiras, debaixo das botas (...) debaixo da cama". A música é pura carnavalização: contra o interdito militar, a festa, seguindo os passos da mais popular das escolas de samba, a 
MIRANDA, Dilmar. Carnavalização e multidentidade cultural: antropofagia e tropicalismo. Tempo Social; Rev. Sociol. USP, S. Paulo, 9(2): 125-154, outubro de 1997.

Estação Primeira de Mangueira. No meio de todo o carnaval, quase às escondidas, como o passeio pela floresta, uma rápida e gaiata citação da Internacional Comunista.

\section{Coda}

Invadir as salas de jantar e participar do banquete antropofágico. Devorar o prato ainda quente e queimar o beiços. Entrar em todas as estruturas, sair delas e fazê-las implodir. Derrubar todas as prateleiras. "Seja marginal, seja herói" ."É proibido proibir". O tropicalismo representou, há exatos trinta anos, um grande esforço de multidentidade alternativa. Hoje, neste fin-desiècle fin-de-millenium pós-tudo, o grande embate que se impõe às culturas musicais riquíssimas, como a brasileira, é o de se mostrarem aguerridamente afirmativas contra esse processo anulador da alteridade. É saber carnavalizar e canibalizar o desafio da contemporaneidade, sem se deixar devorar pela mesmidade globalizada. Contra a "macumba para turista", a proposta de "turista para macumba". Contra a arrogância colonizadora do único e do mesmo, a altivez festiva e resistente do múltiplo e do diferente.

Por que não? Por que não? Por que não?

Só a Antropofagia nos une...

Recebido para publicação em abril/1997

\section{Notas}

${ }^{1}$ Apud José Ramos Tinhorão (1990, p. 42).

${ }^{2}$ Não nos interessa considerar apenas o tríduo festivo que precede o período da quaresma. Estaremos voltados sobretudo para o fenômeno da carnavalização, enquanto postura e visão de vida e de mundo. O carnaval propriamente dito expressa um momento forte de tal fenômeno.

${ }^{3}$ Dos filmes apresentados, no curso sobre Cultura Brasileira e suas Manifestações Estéticas - anos 60/70, do prof. Marco Antonio Guerra, da ECA-USP, o carnaval estava ausente em apenas dois: Deus e diabo na terra do sol de Glauber Rocha e Lúcio Flávio, passageiro da agonia de Hector Babenco. Os outros eram: Terra em transe de Glauber Rocha, Os condenados (do romance "Alma" da trilogia de Oswald de Andrade) de Zelito Viana, Aleluia Gretchem de Silvio Back, Macunaíma (do romance homônimo de Mário de Andrade) de Joaquim Pedro de Andrade, Os herdeiros de Cacá Diegues e A lira do delírio de Walter Lima Jr. Neste, o carnaval não serve apenas como momentos preciosos de marcação recorrente da narrativa, mas se apresenta como elemento estruturante de todo o filme. Sua inteligibilidade só é possível pela hermenêutica do fenômeno da carnavalização que pretendemos aqui analisar.

${ }^{4}$ Trata-se apenas da produção musical realizada fora do período carnavalesco, as músicas 
de meio de ano, como eram chamadas. Não estamos levando em conta marchinhas, marchas-rancho, sambas e sambas-enredo, frevos, intencionalmente criados para o carnaval, cumprindo o papel específico para animar bailes dos clubes ou desfiles das escolas de samba, podendo eventualmente revelar, através de suas letras, o fenômeno da carnavalização aqui analisado.

5 Outro exemplo interessante de presença do carnaval, na literatura, é o romance Dona Flor e seus dois maridos, de Jorge Amado, onde o primeiro marido, Vadinho, morre em plena folia carnavalesca, embora essa obra, como outras mais recentes, tenha transformadose em "macumba para turista", indo, portanto, no contra-fluxo das pretensões do movimento antropofágico e do tropicalismo.

${ }^{6}$ Um exemplo mais recente da carnavalização em nossa dramaturgia (1995) é a peça de Ariano Suassuna, a Farsa da boa preguiça, produzida por um canal de TV. É interessante observar o tratamento carnavalesco da farsa, pela estética da grotesca maquiagem exagerada das personagens, no melhor estilo felliniano, mesclada com a linguagem de literatura de cordel do Nordeste brasileiro. Em seu desfecho, santos e pecadores, seres celestiais e infernais, bons e maus, inocentes e trapaceiros, enfim, todos se reúnem numa grande festa de congraçamento carnavalesco, desfazendo-se as antinomias presentes no decorrer de toda a trama farsesca.

${ }^{7}$ A referência ao texto de Bakhtin foi feita de forma bastante livre, conservando-se os grifos autor.

${ }^{8}$ No Brasil, o sentido iniciático do carnaval, como veremos, está representado, em vários momentos, principalmente no movimento antropofágico (o "acontecimento religioso da raça") e no tropicalismo.

${ }^{9}$ Esse princípio seminal arquetípico nos permite remeter, analogamente, ao princípio fundante do trágico dionisíaco, em $O$ nascimento da tragédia de Nietzsche. Para o filósofo alemão, Dioniso é o deus da festa, da música, e do delírio místico. Procurando travar o bom combate contra os excessos apolíneos da estética clássica grega na arte de seu tempo, Nietzsche ataca a exclusividade do critério das formas harmoniosas do belo e do bom (kalón kai agathón) da tradição socrática. Indaga o filósofo: se é próprio da arte suscitar o prazer estético, como resolver tal exigência na arte trágica? E na arte grotesca? Indagaríamos nós, dentro da perspectiva bakhtiniana: "Comment le laid et le disharmonique, comment le contenu du mythe tragique, peuvent-ils provoqué un plaisir esthétique?" (Nietzsche, 1977, p. 153). O postulado fundante da reflexão nietzscheana afirma que o terrível, o feio, o desarmonioso do mundo e da existência (o equivalente ao grotesco de Bakhtin) só podem ser enfrentados esteticamente. As dissonâncias da existência fazem parte de "un jeu esthétique", e a música seria a arte por excelência capaz de enfrentar tal jogo. A dissonância musical usada para propiciar o prazer da resolução tensão/repouso traduziria, na arte trágica, um desejo de ouvir para além do meramente audível, da mesma forma que o olhar trágico significaria um olhar para além do meramente visível.

${ }^{10}$ Em outro contexto religioso e época histórica, é curioso constatar a existência de um costume na Igreja Católica onde o papa é advertido, sobretudo em ocasiões de muita pompa e luxo, com a seguinte frase: sic transit gloria mundi, para lembrar a provisoriedade e finitude da vida terrena.

11 "A liberdade é uma virtude pagã", afirma uma personagem de A lira do delírio.

${ }^{12}$ O livro Coena Cypriani, em diversas ocasiões, é citado por Eco em $O$ nome da rosa. Numa de suas passagens, o autor coloca na boca do monge Jorge, as seguintes palavras: "Olha os jovens monges que se desavergonham na paródia bufonesca da Coena Cypriani. Que diabólica transfiguração da sagrada escritura!” (p. 534).

${ }^{13} \mathrm{O}$ caráter de festividade e de banquete é um traço constituinte marcante do fenômeno da carnavalização/canibalização tanto do movimento antropofágico oswaldiano como do tropicalismo, conforme veremos adiante.

${ }^{14} \mathrm{Um}$ dos filmes mais cômicos do cinema italiano que explora, de forma extraordinária, este veio paródico-quixotesco do realismo grotesco é $O$ incrível exército de Brancaleone, do diretor Mario Monicelli, tendo o ator Vitório Gasmann no papel análogo ao "cavaleiro 
MIRANDA, Dilmar. Carnavalização e multidentidade cultural: antropofagia e tropicalismo. Tempo Social; Rev. Sociol. USP, S. Paulo, 9(2): 125-154, outubro de 1997.

da triste figura".

${ }^{15}$ Antecipando articulações já anunciadas sobre a carnavalização, no antropofagismo e no tropicalismo, merece citação a interessante canção D. Quixote de autoria de Arnaldo Batista e Rita de Os Mutantes, participantes do disco Tropicália. Sua menção justificase, além do tema, pelo uso de aliterações e de paronomásias, tão ao gosto da poesia antropofágica e tropicalista, sobretudo em Caetano Veloso:

$$
\begin{aligned}
& \text { A vida é o moinho } \\
& \text { É o sonho, é o caminho } \\
& \text { E do Sancho o Quixote } \\
& \text { Chupando chiclete. } \\
& \text { O Sancho tem chance } \\
& \text { E a chance é o chicote } \\
& \text { É o vento é a morte } \\
& \text { Mascando o Quixote. }
\end{aligned}
$$

${ }^{16}$ Essa ambivalência, da morte prenhe, da morte geradora, está também extraordinariamente expressada, num registro estético e plástico diferentes, sem os traços do grotesco, no belo filme $200 \mathrm{l}$ - uma odisséia no espaço. Nas cenas finais, o diretor Stanley Kubrick, a partir da ficção de Arthur Clarke, mostra o protagonista agonizando no seu leito de morte, estendendo a mão em direção ao monolito que desafia os humanos, desde a "alvorada da humanidade". O velho moribundo cede lugar a uma criança-feto com olhar adulto, talvez um novo homem, capaz de compreender o mistério contido no monolito. Na cena, portanto, momentos diferentes expressando o sentido unitário e ambivalente de uma mesmas realidade : como as velhas gravidas, um corpo agonizante-nascente.

${ }^{17}$ A morte tem sido tema constante no carnaval brasileiro. O mais comum é o uso da máscara de caveira. Alguns foliões chegam a se fantasiar completamente com a figura da morte, com o uso inclusive, da tradicional foice que ceifa a vida.

${ }^{18} \mathrm{O}$ uso irônico de atributos grandiloquientes - manhã resplandente candente fagueira por parte do "poeta-oficial-parnasiano" da canção Geléia geral de Gilberto Gil e Torquato Neto, parece ter alvo certo.

${ }^{19}$ A crise estaria sendo provocada, sobretudo, por motivos identificados em dois flancos: a) no interior da própria MPB, pelo esgotamento da bossa nova, devido à divisão interna do próprio movimento (música engajada x alienada, como eram denominadas as duas posições antagônicas, na época, quando se exigia maior compromisso dos artistas na luta contra a ditadura militar); pelo esvaziamento do programa de televisão $O$ fino da bossa, comandado por Elis Regina e Jair Rodrigues; pela retomada do sambão tradicional, muito presente em outro programa de TV, o Bossaudade, comandado pela cantora Elisete Cardoso; b) no plano externo à MPB, a explosão do rock internacional, sobretudo com a beatlemania, bem como a grande aceitação do $i \hat{e}-i \hat{e}-i \hat{e}$ nacional. A grande ameaça era sentida, pela crescente audiência do programa Jovem Guarda, comandado por Roberto e Erasmo Carlos e por Vanderléia. Assim, adeptos do iê-iê-iê traziam para o interior do país temática, melodia, harmonia e ritmos totalmente estranhos à tradição da cultura musical brasileira, com grande aceitação por parte da juventude, até então privilegiada reserva de mercado da moderna música popular brasileira.

20 "Só retomando a linha evolutiva pode nos dar uma organicidade para selecionar e ter um julgamento de criação (...). Aliás, JG para mim é exatamente o momento em que isto aconteceu: a informação da modernidade musical utilizada na recriação, na renovação, no dar um passo à frente da MPB. Creio mesmo que a retomada da tradição da MB deverá ser feita na medida em que JG fez. Apesar de artistas como Edu Lobo, Chico, Gil, Betânia, Gal (que pouca gente conhece) sugerirem esta retomada, em nenhum deles ela chega a ser inteira, integral" (depoimento de Caetano Veloso apud Barbosa, 1966, p. 378).

${ }^{21}$ Instituto Superior de Estudos Brasileiros: instituição para-oficial, espécie de retaguarda da produção ideológica durante a gestão nacional-desenvolvimentista-populista dos presidentes Juscelino Kubistcheky e João Goulart, fechado pela ditadura militar, em 1964.

${ }^{22}$ Caetano, aparentando expressar o lado neo-modernista da Tropicália, reverencia, na 
verdade, o modernismo do início do século, ao reinventar a estética da bricolagem, forma usada, por exemplo, pelo compositor francês Eric Satie, no seu balé Parade de 1917 (obra emblemática do movimento modernista europeu, fortemente presente na Semana de Arte Moderna de 22), pela incorporação de motivos de várias e diferentes procedências musicais.

${ }^{23}$ Integram o projeto, os seguintes artistas: Caetano, Gil, Gal, Torquato Neto, Tom Zé, Capinam, Mutantes, Rogério Duprat e Nara Leão.

${ }^{24}$ Está se constituindo numa tradição brasileira estender o tríduo carnavalesco. Começa-se muito antes, principalmente se levarmos em conta o período de ensaios das escolas de samba ou de tantas outras agremiações e sociedades carnavalescas e estica-se a festa para além da quarta-feira de cinzas.

${ }^{25}$ É impossível evitar a associação com o costume dos enterros da população negra de New Orleans, embora a alternância entre o sagrado e o profano siga uma dinâmica inversa à do carnaval baiano. Na ida ao cemitério, familiares e amigos do morto são acompanhados por uma formação musical típica, originária do século passado, as brass band, que executa pausadamente marchas fúnebres, em clima de total tristeza. Na volta, percorridos cerca de dois quarteirões, as mesmas pessoas, até então tristes e compungidas, são animadas pela mesma banda, agora no ritmo alegre do melhor estilo dixieland, típico do jazz do início deste século de New Orleans. (cf. depoimento de Bunk Johnson apud Hobsbawm, 1990, p. 62). Dimensões antinômicas e díspares - sagrado e profano - integradas no mesmo rito.

${ }^{26}$ Para quem desejar uma análise completa das canções do disco, inclusive de sua dimensão semiótica, cf. Celso Favaretto (1996), ao qual devemos muitas das reflexões aqui apresentadas. Seu livro contém inclusive as letras de todas as canções do ciclo Tropicalista.

${ }^{27}$ José Ramos Tinhorão, em entrevista, afirma que a tragicidade contida no tema do assassinato da mãe como prova das juras de amor seria comum no imaginário da cultura árabe herdado pelos portugueses.

${ }^{28}$ Referência de Caetano ao Solar da Fossa, antigo casarão (atual Shopping Rio Sul) onde muitos artistas recém-chegados ao Rio, em início de carreira, inclusive Caetano, moraram ou se hospedaram.

${ }^{29}$ Para uma visão mais articulada das diferentes expressões estéticas do movimento tropicalista envolvendo, além da música, o teatro de José Celso Martinez, o cinema de Glauber Rocha e as artes plásticas, sobretudo de Gerchman e Hélio Oiticica, cf. Tropicália, 20 anos (1988).

${ }^{30} \mathrm{O}$ primeiro a manifestar esse tipo de ufanismo parece ter sido o compositor do início deste século, Eduardo das Neves, na modinha dedicada ao feito de Santos Dumont, o sobrevôo em Paris em 1902.

A Europa curvou-se ante o Brasil

E clamou parabéns em meigo tom

Surgiu lá no Céu mais uma estrela

Apareceu - Santos Dumont.

(Guimarães, 1978, p. 65). 
MIRANDA, Dilmar. Carnavalização e multidentidade cultural: antropofagia e tropicalismo. Tempo Social; Rev. Sociol. USP, S. Paulo, 9(2): 125-154, outubro de 1997.

MIRANDA, Dilmar. Carnivalization and multi-identity: anthropology and tropicalism. Tempo Social; Rev. Sociol. USP, S. Paulo, 9(2): 125-154, october 1997.

ABSTRACT: Based on Mikhail Bakhtin's studies, this article analyses the carnival and other similar popular parties, both as cultural practices and as a view of life and of the world, crucial phenomena of our so-called cultural identity. In particular the author emphasizes two important movements wich led to intense debates in our cultural life, in two different moments of Brazil's recent history: the Antropofagia of the modernist movement in the 1920's, and the Tropicalismo in the 1960's.

\section{Discografia}

O melhor de Caetano Veloso. (1989) Alegria alegria, Tropicália e Soy loco por ti, América. CD 836.528-2. Phillips.

Gilberto Gil Personalidade. (1987) Domingo no parque. CD M832 216-1. Phillips.

Tropicália ou Panis et Circensis. (1993) Miserere nobis, Coração materno, Panis et circenses, Lindonéia, Parque industrial, Geléia geral, Três caravelas, Enquanto seu lobo não vem e Hino ao Senhor do Bonfim. CD 512 089. Phillips.

\section{REFERÊNCIASBIBLIOGRÁFICAS}

Andrade, Oswald. (1990a) Pau Brasil. São Paulo, Globo. . (1990b) A utopia antropofágica. São Paulo, Globo.

Bakhtin, Mikhail. (1993) A cultura popular na Idade Média e no Renascimento. São Paulo/Brasília, Hucitec.

Barbosa, Airton Lima (coord.). (1966) Que caminho seguir na música brasileira? Revista da Civilização Brasileira, Rio de Janeiro, 7 (I): 375-385.

CAmpos, Augusto de. (1978) Balanço da Bossa e outras bossas. São Paulo, Perspectiva.

CAmpos, Haroldo de. (1990) Introdução. Uma poética da radicalidade. In: Andrade, Oswald. Pau-Brasil. São Paulo, Globo.

DA MATTA, Roberto. (1973) O carnaval como um rito de passagem. In: Ensaios de antropologia estrutural. Petrópolis, Vozes. p. 121-168.

Eco, Umberto. (1995) O nome da rosa. Rio de Janeiro/São Paulo, Ed. Record.

FAvaretto, Celso. (1988) A Canção Tropicalista. In: Tropicália 20 anos. São Paulo, SESC.

UNITERIMS:

carnival, popular parties, cultural practices, cultural identity, modernism. 
. (1996) Tropicália, alegoria alegria. São Paulo, Ateliê Editorial.

FeAtherstone, Mike. (1995) Cultura de consumo e pós-modernismo. São Paulo, Studio Nobel.

GADAmer, Hans-Georg. (1985) A atualidade do belo - a arte como jogo, símbolo e festa. Rio de Janeiro, Tempo Brasileiro.

Guimarães, Francisco. (1978) Na roda do samba. Rio de Janeiro, Funarte.

Hobsbawm, Eric J. (1990) História social do jazz. Rio de Janeiro, Paz e Terra.

NiETzSCHE, Friedrich. (1977) La naissance de la tragédie. Paris, Gallimard.

Prado, Paulo. (1990) Poesia Pau-Brasil. In: Andrade, Oswald. Pau-Brasil. São Paulo, Globo

Santos, Boaventura de Souza. (1995) Pela mão de Alice-o social e o político na pós-modernidade. São Paulo, Cortez.

TinHORÃo, José Ramos. (1990) História social da música popular brasileira. Lisboa, Editorial Caminho.

Tropicália 20 anos. (1988) São Paulo, SESC. 